ISSN (Print) : :1412-7601

ISSN (Online) : 2654-8712

Volume 6, No.2 September 2020

EKONOBIS

http://www.ekonobis.unram.ac.id

\title{
Analisis Peluang Dan Tantangan Penerbitan Sukuk Daerah Sebagai Sumber Pembiayaan Pembangunan Di Nusa Tenggara Barat (NTB)
}

\author{
Irwan Suriadi, Siti Sriningsih, Hailudin
}

Universitas Mataram

\section{ARTICLE INFO}

Keywords :

Regional Sukuk, SWOT

Analysis, West Nusa

Tenggara
ABSTRACT : Economic development requires adequate financing both at the national and regional levels, one of the sources of financing for regional development comes from the issuance of regional Islamic bonds (sukuk). West Nusa Tenggara has a great opportunity to issue regional sukuk as a source of development financing. The purpose of this study is (1) to analyze the opportunities for regional sukuk issuance as a source of financing regional development in West Nusa Tenggara, (2) To find out the obstacles faced in regional sukuk issuance as a source of financing regional development in West Nusa Tenggara (NTB), (3) To find out how the strategy for developing regional sukuk in West Nusa Tenggara. The type of this research is descriptive research, the analysis technique used in this study is SWOT Analysis (Strength, Weakness, Opportunity, Treath). The results show that the existence of various laws and regulations that support the opportunity to obtain loans in the form of regional sukuk and regional Sukuk has the opportunity to accelerate regional economic growth, the obstacle faced by local governments is increasing regional government debt that will affect government debt so will increase the risk of government debt, the strategy for developing regional sukuk is to prepare infrastructure for the sale and purchase of regional sukuk, especially in collaboration with banks and conducting socialization and training related to the delivery of regional sukuk, especially for regional financial management staff..

Kata Kunci : ABSTRAK: Pembangunan ekonomi membutuhkan pembiayaan yang memadai baik di tingkat nasional maupun daerah, salah satu sumber pembiayaan pembangunan daerah berasal dari penerbitan obligasi syariah (sukuk) daerah. Nusa Tenggara Barat memiliki peluang yang besar untuk menerbitkan sukuk daerah sebagai sumber pembiayaan pembangunan.Tujuan dari penelitian ini adalah (1) untuk menganalisis Peluang penerbitan sukuk daerah sebagai sumber pembiayaan pembangunan daerah di Nusa Tenggara Barat, (2) Untuk mengetahui hambatan-hambatan yang dihadapi dalam penerbitan sukuk daerah sebagai sumber pembiayaan pembangunan daerah di Nusa Tenggara Barat (NTB),(3)Untuk mengetahui bagaimana strategi pengembangan sukuk daerah di Nusa Tenggara Barat. Jenis dari penelitian ini adalah penelitian deskriptif, Teknik analisis yang digunakan dalam penelitian ini adalah Analisis SWOT (Strength, Weakness, Opportunity, Treath). Hasil penelitian menunjukkan bahwa adanya berbagai peraturan perundang-undangan yang mendukung adanya peluang untuk memperoleh pinjaman dalam bentuk sukuk daerah dan Sukuk daerah ini berpeluang untuk percepatan pertumbuhan ekonomi daerah, hambatan yang dihadapi oleh pemerintah daerah adalah meningkatkan utang pemerintah daerah yang akan berpengaruh terhadap utang pemerintah sehingga akan meningkatkan risiko utang pemerintah, strategi pengembangan sukuk daerah adalah dengan mempersiapkan infrastruktur untuk penjualan dan pembelian sukuk daerah terutama bekerjasama dengan pihak bank serta melakukan sosialisasi dan pelatihan yang berkaitan dengan penerbitan sukuk daerah terutama bagi staf pengelola keuangan daerah.

Corresponding Author :

Alamat : Program Studi Ekonomi Pembangunan, Fakultas Ekonomi dan Bisnis, Universitas Mataram, Jln. Majapahit No. 62 Mataram.

e-mail: irwansuryadi@unram.ac.id 


\section{PENDAHULUAN}

\section{Latar Belakang}

Keberhasilan pembangunan suatu Negara ditentukan oleh jumlah dana atau anggaran yang dimiliki oleh Negara tersebut, semakin banyak dana pembangunan yang dimiliki maka pembangunan suatu Negara akan lebih mudah tercapai, terutama dalam pembangunan ekonomi suatu Negara. Dana yang tersedia untuk pembangunan salah satunya bersumber dari pembiayaan pembangunan yang dimiliki oleh suatu Negara. Semakin besar pembiayaan yang dimiliki oleh Negara tersebut maka akan semakin besar juga pembangunan ekonomi yang dapat dilaksanakan.

Keberhasilan Pembangunan di tingkat nasional dicerminkan dari keberhasilan pembangunan di tingkat lokal atau daerah, dimana dalam pembangunan terdapat tiga sumber pendanaan yang diberikan dari pemerintah pusat yaitu dana bagi hasil, dana alokasi umum (DAU), dana alokasi khusus (DAK), sedangkan sumber pembiayaan daerah berasal dari Pendapatan Asli Daerah (PAD). Ketika pemerintah daerah ingin melaksanakan pembangunan yang sesuai dengan program yang sudah ada, maka seringkali pemerintah daerah kekurangan dana dalam melaksanakan pembangunan yang diinginkan sehingga diperlukan sumber pemdanaan atau pembiayaan pembangunan lainnya yang menjadi sumber dana peemerintah daerah.

Dengan dikeluarkannya undangundang nomor 33 tahun 2004 tentang perimbangan keuangan antara pemerintah daerah dengan pemerintah pusat, dimana pemerintah pusat memberikan peluang kepada pemerintah daerah untuk mencari sumber dana lainnya untuk pembangunan daerah. Salah satu sumber pendanaan pembangunan daerah dapat dilakukan dengan menerbitkan obligasi daerah baik dengan obligasi daerah yang berbasis bunga atau yang berbasis syariah (sukuk). Dari data otoritas jasa keuangan (OJK) jumlah sukuk yang beredar di Indonesia dan jumlah nilai akumulasi penerbitannya cukup menunjukkan perkembangan yang baik dimana setiap tahun mengalami kenaikan dari tahun 2012 Sampai dengan januari 2018, 
Grafik 1.Statistik Sukuk (obligasi syariah)

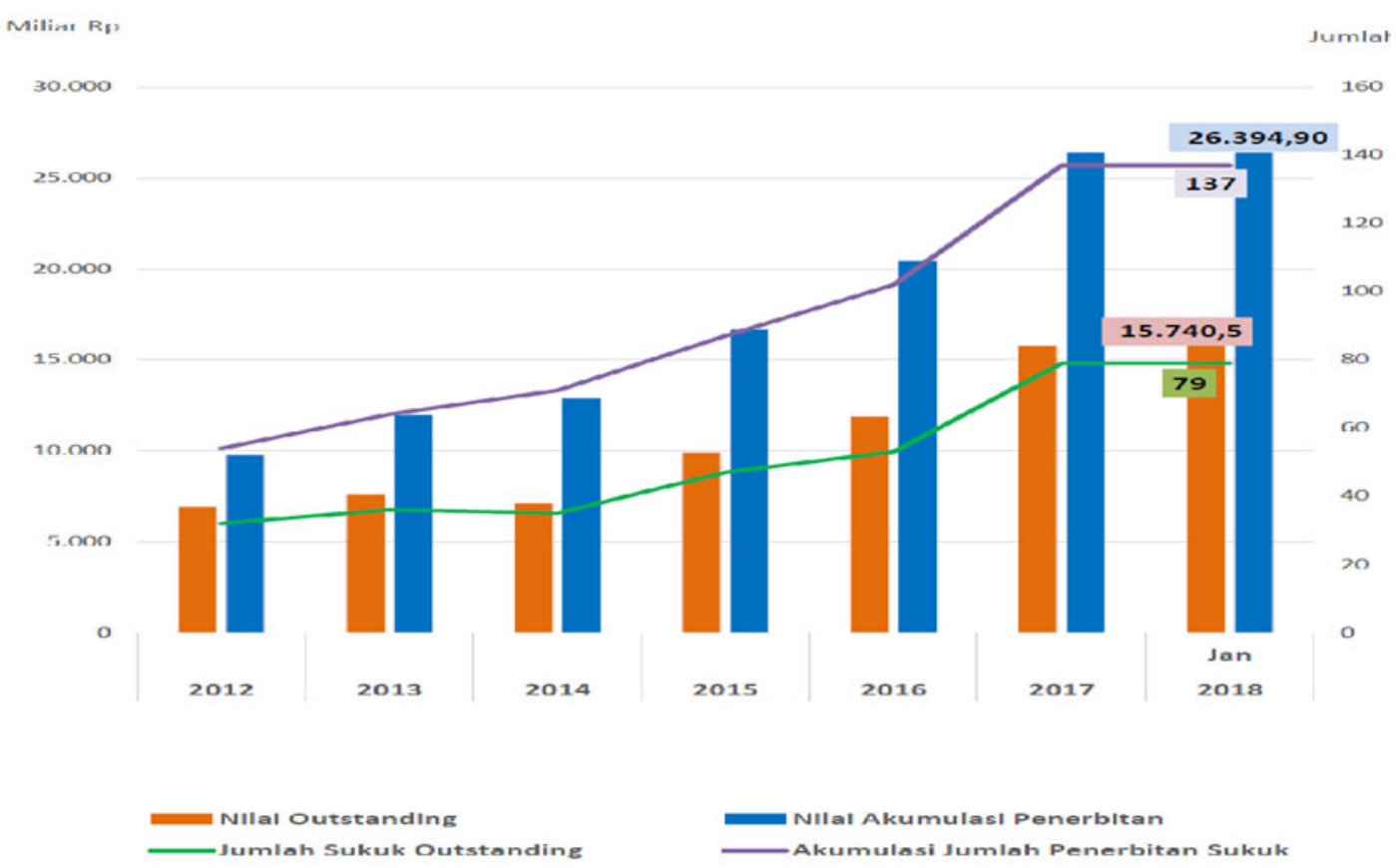

Sumber : http://www.ojk.go.id/id/kanal/syariah/Statistik-Sukuk-Syariah-2018

Pembangunan di Nusa Tenggara Barat sangat membutuhkan pendanaan yang memadai karena banyak ketertinggalan pembangunan yang harus dikejar atau disebut dengan percepatan pembangunan, diantaranya pembangunan dalam mengentaskan kemiskinan, gizi buruk, pendidikan, infrastruktur, pertanian dan lain sebagainya.

Salah satu sumber pembiayaan pembangunan yang dapat dilakukan pemerintah daerah Nusa Tenggara Barat (NTB) adalah melalui penerbitan obligasi daerah syariah atau Sukuk syariah. Peluang dalam penerbitan sukuk daerah syariah di nusa tenggara barat sangat besar peluangnya karena nusa tenggara barat mulai memperkenalkan sistem ekonomi islam, dimana sistem ekonomi islam yang telah dijalankan oleh pemerintah daerah Nusa Tenggara Barat (NTB) adalah adanya hotel syariah di NTB, bank BPD syariah (NTB Syariah), munculnya berbagai lembaga keuangan mikro syariah seperti BMT syariah, Koperasi Syariah dan sebagainya. Peluang diterbitkannya sukuk daerah syariah sebagai sumber pembiayaan pembangunan daerah cukup besar karena beberapa tahun lalu pemerintah NTB telah melakukan promosi investasi ke Negara-negara timur tengah yang menjadi basis investor syariah dunia sehingga 
investor timur tengah dapat melakukan investasi ke pasar modal Indonesia melalui investasi sukuk di NTB pada khususnya dan Indonesia pada umumnya.

Obligasi daerah mulai diperkenalkan pemerintah pusat pada tahun 2006 beriringan dengan penerbitan peraturan perundang-undangan yang mengatur tentang mekanisme penerbitan dan penjualan obligasi daerah yang memberikan banyak peluang bagi pemerintah daerah di seluruh Indonesia untuk mencari sumber pembiayaan lain melalui penerbitan obligasi daerah.

Pemerintah daerah yang ingin menerbitkan obligasi daerah konvensional maupun obligasi daerah yang berbasis syariah atau sukuk daerah harus melakukan kajian kelayakan penerbitan obligasi daerah terlebih dahulu, terutama obligasi daerah yang berbasis sukuk daerah karena tidak semua daerah dapat menerbitkan sukuk daerah, Nusa Tenggara Barat (NTB) memiliki peluang yang besar dalam menerbitkan obligasi daerah syariah (Sukuk) karena memiliki konsentrasi untuk mengembangkan ekonomi syariah di nusa tenggara barat (NTB), selain itu juga pemerintah daerah yang akan menerbitkan sukuk syariah harus memperhatikan juga kemampuan keuangan pemerintah daerah dan kemampuan manajemen keuangan daerah agar tidak terjadi permasalahan di kemudian hari, oleh karena itu diperlukan kajian atau penelitian tentang penerbitan obligasi daerah syariah (Sukuk) di nusa tenggara barat (NTB) dengan judul "Analisis Peluang Dan Tantangan Penerbitan Sukuk Daerah Sebagai Sumber Pembiayaan Pembangunan Di Nusa Tenggara Barat (NTB)

\section{Perumusan Masalah}

1. Bagaimana Peluang penerbitan sukuk daerah sebagai sumber pembiayaan pembangunan daerah di Nusa Tenggara Barat

2. Bagaimana hambatan-hambatan yang dihadapi dalam penerbitan sukuk daerah sebagai sumber pembiayaan pembangunan daerah di Nusa Tenggara Barat

3. Bagaimana strategi pengembangan sukuk daerah di Nusa Tenggara Barat

\section{Tujuan Penelitian}

1. Untuk menganalisis Peluang penerbitan sukuk daerah sebagai sumberpembiayaan pembangunan daerah di Nusa Tenggara Barat 
2. Untuk mengetahui hambatanhambatan yang dihadapi dalam penerbitan sukuk daerah sebagai sumberpembiayaan pembangunan daerah di Nusa Tenggara Barat (NTB)

3. Untuk mengetahui bagaimana strategi pengembangan sukuk daerah di Nusa Tenggara Barat

\section{Manfaat penelitian}

1. Membantu Pemerintah daerah Nusa Tenggara Barat dalam mencari sumber pembiayaan pembangunan daerah.

2. Membantu pemerintah daerah Nusa Tenggara Barat dalam mempromosikan investasi daerah melalui penerbitan sukuk daerah kepada investor dalam dan luar negeri.

3. Secara teoritis sebagai tambahan referensi bagi pihak-pihak yang ingin melakukan penelitian lebih lanjut berkaitan dengan sukuk daerah.

\section{KAJIAN PUSTAKA}

\section{Penelitian Terdahulu}

Naufal,et.al (2017) melakukan penelitian yang berjudul "Do regional and global uncertainty factors affect differently the conventional bonds and sukuk? New evidence".Tujuan dari penelitian ini adalah menganalisis apakah factor global dan regional berpengaruh terhadap obligasi konvensional dan obligasi Negara (sukuk). Metode analisis yang digunakan adalah analisis regresi dengan menggunakan data dari periode Januari 2010 sampai Desember 2014. Hasil Penelitian ini menunjukkan bahwa secara empiris menunjukkan kemandirian antara sukuk return dan ketidakpastian kebijakan ekonomi global dan regional untuk semua quantiles, namun hubungan kausalitas saat pasar bearish. Namun, peneliti menemukan hubungan antara pergerakan dan kausalitas antara pasar obligasi konvensional dan faktor ketidakpastian keuangan dan ekonomi global. Sebagai perbandingan, peneliti menguji dampak faktor ketidakpastian global dan regional terhadap sukuk return dalam kasus pasar sukuk negara terbesar di dunia yang diperuntukkan bagi Malaysia. Temuan peneliti menunjukkan bahwa sukuk berbeda dari obligasi konvensional dalam hal comovement dengan faktor ketidakpastian global dan regional dan kedua aset ini saling melengkapi dan bukan sebagai pengganti. 
Putra (2017) melakukan penelitian tentang "Pemanfaatan Sukuk Untuk Alternatif Pembiayaan Dan Investasi Daerah (Studi Pada Kabupaten Malang)". Tujuan dari penelitian ini adalah untuk (1) menganalisis kemampuan Kabupaten Malang dalam melakukan pinjaman dan proyeksi pinjaman yang dapat dilakukan dalam bentuk obligasi syariah; dan (2) mensimulasi strategi-strategi untuk menerbitkan sukuk (obligasi syariah) sebagai alternatif pembiayaan daerah di Kabupaten Malang. Metode penelitian yang digunakan adalah deskriptif kuantitatif. Metode pengumpulan data meliputi wawancara, survey, dokumentasi dan observasi.

Hasil penelitian menunjukkan bahwa Kabupaten Malang mampu dalam melakukan pinjaman baik jangka pendek maupun jangka panjang yang dicerminkan melalui indikator Debt Service Coverage Ratio (DSCR) selama 3 (tiga) tahun terakhir (2014-2016) sebagai berikut: 48,40; 73,48; dan 15,04. Sedangkan proyeksi pinjaman untuk Kabupaten Malang dihitung menggunakan regresi linier sederhana. Proyeksi pinjaman Kabupaten Malang secara berturut- turut, yaitu 1.217 miliar rupiah (2017), 1.331 miliar rupiah (2018), 1.445 miliar rupiah (2019), 1.559 miliar rupiah (2020) dan 1.673 miliar rupiah (2021).

Armadiyanti (2013) meneliti tentang peluang dan tantangan perkembangan obligasi syariah (sukuk) di Indonesia, tujuan penelitiannya adalah untuk mengetahui peluang dan tantangan perkembangan obligasi syariah (sukuk) di Indonesia, metode penelitian yang digunakan oleh peneliti adalah jenis penelitian deskriptif dengan menggunakan studi kepustakaan. Hasil penelitian menunjukkan bahwa Potensi-potensi yang menjadi peluang dalam mendukung pengembangan obligasi syariah (sukuk) di Indonesia antara lain, yaitu: (a) sukuk sebagai potensi penyaluran likuiditas yang aman; (b) populasi penduduk muslim Indonesia yang besar; (c) pertumbuhan ekonomi Indonesia yang menjanjikan;(d) sukuk sebagai alternatif cadangan defisit APBN dan kebijakan moneter. Beberapa tantangan harus dihadapi oleh Indonesia terkait dengan perkembangan obligasi syariah antara lain: (a) terbatasnya Sumber Daya Manusia dan pemahaman pelaku pasar terhadap produk pasar modal syariah; 
(b) kurangnya sosialisasi terhadap produk syariah terutama obligasi syariah; (c) masih terbatasnya jenis akad dan produk pasar modal syariah; (d) regulasi terkait pasar modal syariah yang kurang update; (e) sulitnya pembentukan Special Purpose Vehicle (SPV); (f) perlakuan sukuk tidak diatur dalam PSAK syariah.

Okta \& Kaluge, (2012) melakukan penelitian yang berjudul "Analisis Peluang Penerbitan Obligasi Daerah Sebagai Alternatif Pembiayaan Daerah" Tujuan penelitiannya adalah untuk (1) menganalisis kelayakan penerbitan obligasi daerah sebagai sumber pembiayaan alternatif infrastruktur local, (2) menganalisis strategi yang akan dilaksanakan oleh pemerintah dalam penerbitan obligasi daerah. Alat analisis yang digunakan dalam penelitian ini adalah deskriptif statistik dan analisis SWOT. Hasil penelitian menunjukkan bahwa Obligasi daerah merupakan alternatif yang layak dipertimbangkan sebagai sumber pembiayaan daerah dibandingkan pendanaan yang lain. Kelebihan obligasi daerah sebagai alternatif pendanaan pembangunan, antara lain mampu menarik minat pemilik dana untuk berinvestasi, mampu menyediakan dana dalam jumlah besar, memiliki risiko yang rendah atas perubahan kurs, memiliki risiko yang rendah atas perubahan kebijakan pemerintah. Beberapa strategi dapat ditempuh oleh pemerintah daerah dalam rangka penerbitan obligasi daerah antara lain memanfaatkan semangat membangun yang dimiliki masyarakat daerah serta potensi masyarakat daerah untuk pembangunan daerah melalui penerbitan obligasi daerah, mengikutsertakan masyarakat dalam mekanisme pengawasan proyek dalam rangka meminimize kemungkinan terjadinya moral hazard oleh pejabat daerah, perlu segera dibuat aturan/aspek legal dari penerbitan obligasi daerah, perlu disiapkan infrastruktur dan outlet untuk melayani penjualan dan pembelian obligasi daerah, penerbitan obligasi daerah dibuat dalam bentuk retail/ nilai nominal kecil agar dapat dijangkau oleh masyarakat daerah, penerbitan obligasi daerah oleh Badan Otorita Daerah atau BUMD dan pembayaran kupon dan pelunasan obligasi sepenuhnya menjadi tanggung jawab Penerbit Obligasi, sehingga tidak membebani APBD. 
Simonsen, et.al (2001) melakukan penelitian yang berjudul " The Influence of Jurisdiction Size and Sale Type on Municipal Bond Interest Rates: An Empirical Analysis.Tujuan penelitian nya adalah untuk menganalisis pengaruh ukuran, tipe dan tingkat bunga obligasi daerah, data yang digunakan adalah data penjualan obligasi kota di Oregon dari tahun 1994 sampai 1997 untuk mengeksplorasi apakah populasi (sebagai proxy untuk kapasitas pengelolaan keuangan) dan jenis penjualan (kompetitif atau negosiasi penjualan) mempengaruhi tingkat suku bunga. Hasil penelitiannya menunjukkan bahwa yurisdiksi yang lebih kecil membayar denda biaya bunga di pasar obligasi daerah, dan bahwa hasil penjualan yang kompetitif secara signifikan menurunkan suku bunga dibandingkan dengan penjualan yang dinegosiasikan. Penulis menyarankan agar langkah-langkah untuk meningkatkan kapasitas pengelolaan keuangan pemerintah daerah diperlukan dan bahwa undangundang negara bagian yang mewajibkan pembenaran untuk penjualan yang dinegosiasikan harus sesuai dengan perundang-undangan.
Poeterba \& Robin (1997) melakukan penelitian yang berjudul "State Fiscal Institutions And The U.S. Municipal Bond Market" penelitian ini ingin melihat pengaruh lembaga fiskal negara, terutama peraturan anggaran berimbang dan pembatasan penerbitan utang negara, terhadap imbal hasil obligasi Negara. Peneliti menganalisis informasi dari Survei Nilai Relatif Chubb, yang berisi imbal hasil bebas pajak pada obligasi yang diterbitkan oleh negara bagian yang berbeda selama periode 1973-1996. Hasil penelitian ini menunjukkan bahwa negara-negara bagian dengan peraturan anti-defisit yang lebih ketat, dan ketentuan yang lebih ketat mengenai kewenangan legislatif negara bagian untuk mengeluarkan hutang, membayar suku bunga yang lebih rendah untuk obligasi mereka. Perbedaan suku bunga antara negara dengan konstitusi fiskal anti-defisit yang sangat ketat, dan yang satu dengan konstitusi lemah, adalah antara lima belas dan dua puluh basis poin. Negara-negara dengan batas pendapatan yang mengikat cenderung menghadapi tingkat pinjaman yang lebih tinggi dengan jumlah yang hampir sama, sementara negara-negara 
dengan batas pengeluaran menghadapi biaya pinjaman yang lebih rendah. Dengan demikian, pembatasan fiskal yang mengendalikan pengeluaran dipandang baik oleh peserta pasar obligasi, sementara itu yang membatasi pajak, dan oleh karena itu dapat mengganggu kemampuan negara untuk melunasi bunga, mengakibatkan biaya pinjaman lebih tinggi. Efek dari institusi fiskal yang ketat sangat terlihat ketika ekonomi negara lemah. Hasil ini memberikan bukti penting bahwa peserta pasar obligasi menganggap institusi fiskal dalam menilai karakteristik risiko dari obligasi bebas pajak, dan selanjutnya mendukung pandangan bahwa institusi fiskal memiliki dampak nyata terhadap hasil kebijakan.

\section{Landasan Teori}

1.Obligasi Daerah

Menurut Peraturan Menteri Keuangan Nomor 147/PMK.07/2006 tentang Tata Cara Penerbitan, Pertanggungjawaban, dan Publikasi Informasi Obligasi Daerah, maka pengertian obligasi daerah adalah Pinjaman Daerah yang ditawarkan kepada publik melalui penawaran umum di pasar modal.Pengertian tersebut sesuai dengan pengertian obligasi daerah dalam Peraturan Pemerintah nomor 54 tahun 2005 tentang pinjaman daerah. Obligasi Daerah merupakan surat utang yang diterbitkan oleh pemerintah daerah yang ditawarkan kepada publik melalui penawaran umum di pasar modal. Obligasi ini tidak dijamin oleh Pemerintah Pusat (Pemerintah) sehingga segala resiko yang timbul sebagai akibat dari penerbitan Obligasi Daerah menjadi tanggung jawab Pemerintah Daerah. Penerbitan surat utang merupakan bukti bahwa pemerintah daerah telah melakukan pinjaman/utang kepada pemegang surat utang tersebut. Pinjaman akan dibayar kembali sesuai dengan jangka waktu dan persyaratan yang disepakati. Pemerintah daerah yang menerbitkan obligasi daerah berkewajiban membayar bunga secara berkala sesuai dengan jangka waktu yang telah ditetapkan.Pada saat jatuh tempo pemerintah daerah berkewajiban mengembalikan pokok pinjaman. Tujuan dari penerbitan Obligasi Daerah adalah untuk membiayai suatu kegiatan investasi sektor publik yang menghasilkan penerimaan dan memberikan manfaat bagi masyarakat.Untuk itu perlu diperhatikan bahwa penerbitan obligasi 
tidak ditujukan untuk menutup kekurangan kas daerah.Obligasi Daerah akan diperjualbelikan di pasar modal dalam negeri sesuai dengan peraturan perundang-undangan pasar modal (Okta \& Kaluge,2012)

2.Karakteristik Obligasi Daerah

Berdasarkan Peraturan Pemerintah Nomor 54 Tahun 2005 tentang Pinjaman Daerah, yang berisi bahwa obligasi daerah yang diterbitkan hanya jenis obligasi pendapatan (revenue bonds) saja. Setiap kegiatan yang didanai melalui penerbitan obligasi daerah harus menghasilkan penerimaan, namun tidak harus mencapai pemulihan biaya penuh dan apabila kegiatan belum menghasilkan dana yang cukup untuk membayar pokok, bunga, dan denda maka pembayaran dilakukan dari APBD daerah yang menerbitkan obligasi daerah tersebut. Adapun Karakteristik Obligasi Daerah terdiri dari (Okta \& Kaluge,2012). Obligasi merupakan pinjaman jangka panjang yang berasal dari masyarakat (lebih dari satu tahun sesuai dengan syarat perjanjian pinjaman yang bersangkutan).

Obligasi di Indonesia umumnya mempunyai jangka waktu sekitar 5 tahun atau lebih;
Diterbitkan melalui penawaran umum kepada masyarakat di pasar modal dalam negeri; Dikeluarkan dalam mata uang rupiah;

Hasil penjualan digunakan untuk membiayai investasi sektor publik yang menghasilkan penerimaan dan memberikan manfaat bagi masyarakat; Nilai obligasi daerah pada saat jatuh tempo sama dengan nilai nominal obligasi daerah pada saat diterbitkan.

Menurut Okta \& Kaluge (2012) Pemerintah Daerah dapat menerbitkan Obligasi Daerah hanya untuk membiayai kegiatan investasi sektor publik yang menghasilkan penerimaan dan memberikan manfaat bagi masyarakat yang menjadi urusan Pemerintah Daerah berdasarkan peraturan perundangan yang berlaku. Obligasi yang diterbitkan dapat digunakan untuk membiayai beberapa kegiatan yang berbeda. Kegiatan pemerintah daerah yang dapat dibiayai dengan obligasi daerah di antaranya:
a. pelayanan air minum;
b. penanganan limbah dan persampahan;
c. transportasi;
d. rumah sakit;
e. pasar tradisional;
f. tempat perbelanjaan; 

g. pusat hiburan;
h. wilayah wisata dan pelestarian alam;
i. terminal dan sub terminal;
j. perumahan dan rumah susun;
k. pelabuhan lokal dan regional.

\section{Obligasi syariah (Sukuk)}

Selama ini sebagian besar investasi dipasar modal ditempatkan pada saham dan obligasi. Obligasi pada umumnya dikeluarkan oleh perusahaan (emiten) sebagai surat berharga jangka panjang. Obligasi ini bersifat utang dengan memberikan kupon kepada pemegang obligasi pada waktu tertentu, serta melunasi hutang pokok pada saat jatuh tempo. Bentuk investasi pada obligasi ini dirasa belum mampu memenuhi kebutuhan sebagian besar investor di Indonesia.

Oleh karena itu, praktisi pasar modal di Indonesia meluncurkan obligasi syariah dengan terinspirasi dengan perkembangan perbankan syariah yang cukup menjanjikan. Konsep syariah ini mempunyai prinsip bagi hasil atau profit-lost sharing yang berasal dari usaha perusahaan (emiten).

Menurut Fatwa Dewan Syariah Nasional MUI, Obligasi Syariah adalah suatu surat berharga jangka panjang berdasarkan prinsip syariah yang dikeluarkan oleh emiten kepada pemegang obligasi syariah yang mewajibkan emiten untuk membayar pendapatan kepada pemegang obligasi syariah berupa bagi hasil/margin/fee serta membayar kembali dana obligasi pada saat jatuh tempo.

Obligasi syariah juga merupakan obligasi yang ditawarkan dengan ketentuan yang mewajibkan emiten untuk membayar kepada pemegang obligasi syariah dengan sejumlah pendapatan bagi hasil dan membayar kembali dana obligasi syariah pada tanggal pembayaran kembali obligasi syariah tersebut. Pendapatan bagi hasil dapat dibayarkan setiap periode tertentu 3 bulan, 6 bulan atau setiap satu tahun (Raharjo, 2003:40).

Adapun besarnya pendapatan bagi hasil dihitung berdasarkan perkalian antara nisbah pemegang obligasi syariah dengan pendapatan yang dibagi hasilkan, dimana besarnya bagi hasil tercantum dalam laporan konsolidasi emiten triwulanan yang terakhir diterbitkan sebelum tanggal pembayaran pendapatan bagi hasil yang bersangkutan. Pembayaran pendapatan bagi hasil kepada masingmasing pemegang obligasi syariah akan dilakukan secara proporsional sesuai 
dengan proporsi kepemilikan obligasi syariah yang dimiliki dibandingkan dengan jumlah dana obligasi syariah yang belum dibayar kembali.

1. Dasar hukum obligasi syariah (Sukuk) Pelaksanaan obligasi syariah di Indonesia dilakukan atas dasar hukum (Raharjo, 2003:142):

a. Pendapat ulama tentang keharaman mendapatkan bunga.

b. Pendapat ulama tentang obligasi syariah yang menggunakan prinsip mudharabah, murabaha, musyarakah, istisna dan salam.

c. Pendapat ulama tentang keharaman obligasi yang berpenghasilan berbentuk bunga.

d. Fatwa Dewan Syariah Nasional Nomor : 32/DSN-MUI/IX/2002 tentang Obligasi Syariah.

e. Fatwa Dewan Syariah Nasional Nomor : 20/DSN-MUI/IV/2001 mengenai Pedoman Pelaksanaan Investasi Reksadana Syariah.

f. Ketentuan yang harus dipatuhi oleh perusahaan yang ingin menerbitkan obligasi syariah diantaranya (Fatwa DSN-MUI nomor 9/DSN-MUI/IV/2000) :

g. Bidang usaha

h. Bidang usaha yang harus dilakukan oleh emiten tidak boleh bertentangan atau berlawanan dengan prinsip syariah .

i. Pendapatan (hasil)

j. Pendapatan atau hasil investasi yang dibagikan oleh perusahaan penerbit obligasi kepada pemegang obligasi syariah harus benar-benar halal dan tidak bertentangan dengan prinsip syariah yang telah ditetapkan dalam Islam.

k. Obyek ljarah harus berupa manfaat yang diperbolehkan

I. Emiten dalam kedudukannya sebagai penerbit obligasi dapat mengeluarkan obligasi syariah ijarah baik untuk aset yang telah ada maupun aset yang akan ditiadakan untuk disewakan

m. Emiten yang bertindak sebagai wakil dari pemegang obligasi dapat menyewa untuk dirinya sendiri atau menyewakan kepada pihak lain.

n. Pemegang Obligasi Syariah Ijarah sebagai pemilik aset dalam menyewakan asset yang menjadi haknya kepada pihak lain dilakukan melalui emiten sebagai wakil.

o. Dalam hal Emiten bertindak sebagai penyewa untuk dirinya 
sendiri, maka emiten wajib membayar sewa dalam jumlah dan waktu yang disepakati sebagai imbalan sebagaimana jika penyewaan dilakukan kepada pihak lain.

p. Kepemilikan obligasi syariah ijarah dapat dialihkan kepada pihak lain , selama disepakati dalam akad penyelesaiannya dilakukan melalui Badan Arbitrase Syariah setelah tidak tercapai kesepakatan melalui musyawarah.

q. Pengawasan aspek syariah dilakukan oleh Dewan Pengawas Syariah atau Tim Ahli Syariah yang ditunjuk oleh Dewan Syariah nasional MUI, sejak proses emisi Obligasi Syariah Ijarah di mulai.

r. Jika terjadi perselisihan di dalam penerbitan obligasi syariah tersebut, maka harus diselesikan melalui Badan Arbitrase Syariah apabila tidak mendapatkan penyelesaian sepakat di antara pihak-pihak yang bersengketa.

S. Di dalam aturan yang ada, diberikan juga pengertian berkaitan dengan dasar akad (perjanjian) yang dapat digunakan dalam penerbitan obligasi syariah diantaranya akad mudharabah, murabahah, musyarakah, istisna, salam dan ljarah.

2. Karakteristik Obligasi Syariah (Sukuk) Karakteristik yang dimiliki oleh obligasi syariah terdiri dari;

a. Obligasi syariah menekankan pendapatan investasi bukan berdasarkan pada tingkat bunga yang telah ditentukan sebelumnya. Tingkat pendapatan dalam obligasi syariah berdasarkan pada tingkat rasio bagi hasil (nisbah) yang besarannya telah disepakati oleh pihak emiten dan investor.

b. Jenis industri yang dikelola oleh emiten dan hasil pendapatannya perusahaan penerbit obligasi harus terhindar dari unsur yang haram.

c. Dalam sistem pengawasannya selain dilakukan oleh pihak wali amanat, obligasi syariah juga diawasi oleh Dewan Pengawas Syariah (di bawah MUI) sejak dari penerbitan obligasi sampai akhir dari masa penerbitan obligasi tersebut. Dengan adanya sistem ini, maka prinsip kehati-hatian dan perlindungan yang dilakukan oleh perusahaan kepada investor obligasi syariah akan terjamin. 
Karakteristik lainnya dari obligasi syariah adalah:

Pertama, Obligasi syariah menekankan pendapatan investasi bukan berdasar kepada tingkat bunga (kupon) yang telah ditentukan sebelumnya. Tingkat pendapatan dalam obligasi syariah berdasar kepada tingkat rasio bagi hasil (nisbah) yang besarnya telah disepakati oleh pihak emiten dan investor.

Kedua, dalam sistem pengawasannya selain diawasi oleh pihak Wali Amanat maka mekanisme obligasi syariah juga diawasi oleh Dewan Pengawas Syariah (di bawah Majelis Ulama Indonesia) sejak dari penerbitan obligasi sampai akhir dari masa penerbitan obligasi tersebut. Dengan adanya sistem ini maka prinsip kehati-hatian dan perlindungan kepada investor obligasi syariah diharapkan bisa lebih terjamin. Ketiga, jenis industri yang dikelola oleh emiten serta hasil pendapatan perusahaan penerbit obligasi harus terhindar dari unsur non halal.

Secara umum, ketentuan mekanisme mengenai obligasi syariah sebagai berikut :[5]

a. Obligasi syariah haruslah berdasarkan konsep syariah yang hanya memberikan pendapatan kepada pemegang obligasi dalam bentuk bagi hasil atau revenue sharing serta pembayaran utang pokok pada saat jatuh tempo

b. Obligasi syariah mudharabah yang diterbitkan harus berdasarkan pada bentuk pembagian hasil keuntungan yang telah disepakati sebelumnya serta pendapatan yang diterima harus bersih dari unsur non halal

c. Nisbah (rasio bagi hasil) harus ditentukan sesuai kesepakatan sebelum penerbitan obligasi tersebut

d. Pembagian pendapatan dapat dilakukan secara periodic atau sesuai ketentuan bersama, dan pada saat jatuh tempo hal itu diperhitungkan secara keseluruhan

e. Sistem pengawasan aspek syariah dilakukan oleh DPS atau oleh Tim Ahli Syariah yang ditunjuk oleh DSN MUI

f. Apabila perusahaan penerbit obigasi melakukan kelalaian atau melanggar syarat perjanjian, wajib dilakukan pengembalian dana investor dan harus dibuat surat pengakuan utang

g. Apabila emiten berbuat kelalaian atau cedera janji maka pihak investor dapat menarik dananya 
h. Hak kepemilikan obligasi syariah mudharabah dapat dipindahtangankan kepada pihak lain sesuai kesepakatan akad perjanjian.

3. Mekanisme Obligasi Syariah (Sukuk) Menurut fatwa MUI No 20/DSN MUI/IV/2001 mekanisme obligasi syariah adalah;

a. Obligasi syariah harus berdasarkan pada konsep syariah yang hanya memberikan pendapatan kepada pemegang obligasi dalam bentuk bagi hasil atau revenue sharing serta pembayaran hutang pokok pada saat jatuh tempo.

b. Nisbah (rasio bagi hasil) harus ditentukan sesuai dengan kesepakatan sebelum penerbitan obligasi tersebut.

c. Pembagian pendapatan dilakukan secara periodik atau sesuai dengan ketentuan bersama dan pada saat jatuh tempo hal itu diperhitungkan secara keseluruhan.

d. Obligasi syariah ijarah/mudharabah yang diterbitkan oleh emiten haruslah berdasarkan pada bentuk pembagian hasil keuntungan yang telah disepakati sebelumnya dan pendapatan yang diterima harus bersih dari unsur yang haram.

e. Sistem pengawasan aspek syariah dilakukan oleh Dewan Syariah Nasional atau oleh tim ahli syariah yang ditunjuk oleh Dewan Syariah Nasional MUI.

f. Apabila emiten berbuat kelalaian atau cedera janji, maka pihak investor dapat menarik dananya.

g. Apabila perusahaan penerbit obligasi melakukan kelalaian atau melanggar syarat perjanjian, maka wajib dilakukan pengembalian dana investor dan harus dibuat surat pengakuan utang

h. Hak kepemilikan obligasi syariah mudharabah dapat dipindah tangankan kepada pihak lain sesuai dengan kesepakatan pada akad perjanjian di awal.

4. Jenis Obligasi Syariah

Melalui Fatwa No. 32/DSNMUI/IX/2002, DSN sebenarnya mengkategorikan tiga jenis pemberian keuntungan kepada investor pemegang Obligasi Syariah. Pertama, adalah berupa bagi hasil kepada pemegang Obligasi Mudharabah atau Musyarakah. Kedua, keuntungan berupa margin bagi pemegang Obligasi Murabahah, Salam, atau Istishna'. 
Ketiga, berupa fee (sewa) dari aset yang disewakan untuk pemegang Obligasi dengan akad ijarah.

Obligasi syariah dapat diterbitkan dengan menggunakan prinsip mudharabah, musyarakah, ijarah, istisna', salam dan murabahah. Tetapi diantara prinsip-prinsip instrumen obligasi ini yang paling banyak dipergunakan adalah obligasi dengan instrumen prinsip mudharabah dan ijarah :[6]

\section{a. Obligasi Mudharabah}

Obligasi syariah mudharabah adalah obligasi syariah yang menggunakan akad mudharabah. Akad mudharabah adalah akad kerjasama antara pemilik modal (shahibul maal /investor) dengan pengelola (mudharib/emiten). Ikatan atau akad mudharabah pada hakikatnya adalah ikatan penggabungan atau percampuran berupa hubungan kerjasama antara pemilik usaha dengan pemilik harta, dimana pemilik harta (shahibul maal) hanya menyediakan dana secara penuh (100\%) dalam suatu kegiatan usaha dan tidak boleh secara aktif dalam pengelolaan usaha. Sedangkan pemilik usaha (mudharib/emiten) memberikan jasa, yaitu mengelola harta secara penuh dan mandiri.
Dalam Fatwa No. 33 / DSN-MUI / X / 2002 tentang obligasi syariah mudharabah, dinyatakan antara lain bahwa:

1. Obligasi syariah adalah suatu surat berharga jangka panjang berdasarkan prinsip syariah yang dikeluarkan emiten kepada pemegang obligasi syariah yang mewajibkan emiten untuk membayar pendapatan kepada pemegang obligasi syariah merupakan bagi hasil, margin atau fee serta membayar dana obligasi pada saat obligasi jatuh tempo

2. Obligasi syariah mudharabah adalah obligasi syariah yang berdasarkan akad mudharabah dengan memperhatikan substansi fatwa DSN-MUI No. 7 / DSN-MUI / IV / 2000 tentang Pembiayaan Mudharabah

3. Obligasi mudharabah emiten bertindak sebagai mudharib (pengelola modal), sedangkan pemegang obligasi mudharabah bertindak sebagai shahibul maal (pemodal)

4. Jenis usaha emiten tidak boleh bertentangan dengan prinsip syariah 
5. Nisbah keuntungan dinyatakan dalam akad

6. Apabila emiten lalai atau melanggar perjanjian, emiten wajib menjamin pengambilan dana dan pemodal dapat meminta emiten membuat surat pengakuan utang

7. Kepemilikan obligasi syariah dapat dipindahtangankan selama disepakati dalam akad

\section{b.Obligasi ljarah}

Obligasi ljarah adalah obligasi syariah berdasarkan akad ijarah. Akad ijarah adalah suatu jenis akad untuk mengambil manfaat dengan jalan penggantian. Artinya, pemilik harta memberikan hak untuk memanfaatkan objek yang ditransaksikan melalui penguasaan sementara atau peminjaman objek dengan manfaat tertentu dengan membayar imbalan kepada pemilik objek. ljarah mirip dengan leasing, tetapi tidak sepenuhnya sama. Dalam akad ijarah disertai dengan adanya perpindahan manfaat tetapi tidak terjadi perpindahan kepemilikan.

Berdasarkan Fatwa Dewan Syariah Nasional Majelis Ulama Indonesia Nomor 41/DSN-MUI/III/2004 tentang Obligasi Syariah Ijarah,telah ditegaskan beberapa hal mengenai obligasi syariah ijarah, sebagai berikut :[10]

1. Obligasi syariah adalah suatu surat berharga jangka panjang berdasarkan prinsip syariah yang dikeluarkan oleh emiten kepada pemegang obligasi syariah yang mewajibkan emiten untuk membayar pendapatan kepada pemegang obligasi syariah berupa bagi hasil/margin/fee serta membayar kembali dan obligasi pada saat jatuh tempo

2. Obligasi syariah ijarah adalah obligasi syariah berdasarkan akad ijarah dengan memperhatikan substansi Fatwa DSN-MUI No. 09/DSN-MUI/IV/2009 tentang pembiayaan ijarah

3. Pemegang obligasi syariah ijarah (OSI) dapat bertindak sebagai musta'jir (penyewa) dan dapat pula bertindak sebagai mu'jir (pemberi sewa)

4. Emiten dalam kedudukannya sebagai wakil Pemegang OSI dapat menyewa ataupun menyewakan kepada pihak lain dan dapat pula bertindak sebagai menyewa.

Secara teknis, obligasi ijarah dapat dilakukan dengan dua cara, yaitu: 
a. Investor dapat bertindak sebagai penyewa (musta'jir) sedangkan emiten dapat bertindak sebagai wakil investor. Dan property owner, dapat bertindak sebagai orang yang menyewakan (mu'jir). Dengan demikian, ada dua kali transaksi dalam hal ini; transaksi pertama terjadi antara investor dengan emiten, dimana investor mewakilkan dirinya kepada emiten dengan akad wakalah, untuk melakukan transaksi sewa menyewa dengan property owner dengan akad ijarah. Selanjutnya, transaksi terjadi antara emiten (sebagai wakil investor) dengan property owner (sebagai orang yang menyewakan) untuk melakukan transaksi sewa menyewa (ijarah)

b. Setelah investor memperoleh hak sewa, maka investor menyewakan kembali objek sewa tersebut kepada emiten. Atas dasar transaksi sewa menyewa tersebut, maka diterbitkanlah surat berharga jangka panjang (obligasi syariah ijarah), dimana atas penerbitan obligasi tersebut, emiten wajib membayar pendapatan kepada investor berupa fee serta membayar kembali dana obligasi pada saat jatuh tempo. Seperti juga dalam obligasi syariah mudharabah, obligasi syariah ijarah menghadapi tantangan dan kendala yang tidak sedikit.

\section{c.Obligasi Syariah Istishna'}

Adalah obligasi syariah yang diterbitkan berdasarkan perjanjian atau akad istishna' di mana para pihak menyepakati jual beli dalam rangka pembiayaan suatu proyek/barang. Berikut Ketentuan Umum obligasi syariah.[12]

1. Pelaksanaan obligasi syariah mulai dari awal sampai akhir harus terhindar dari format dan substansi akad yang berkaitan dengan riba (pembungaan uang) dan gharar

2. Transaksi obligasi syariah harus berdasarkan konsep muamalah yang sejalan syariah seperti akad kemitraan (musyarakah dan mudharabah), jual beli barang (murabahah, salam, dan istishna)

3. Bagi hasil pada akad kemitraan, fee pada akad ijarah, dan harga (modal dan margin) pada akad jual beli harus ditentukan secara jelas pada awal transaksi (prospectus atau sertifikat) 
4. Usaha yang dilakukan emiten (originator) berhubungan dengan dana sukuk yang dikelola harus terhindar dari semua unsur-unsur non halal

5. Pemberian pendapat dapat dilakukan secara periodik (sesuai karakteristik masing-masing akad)

6. Tidak semua sertifikat sukuk dapat diperjualkan dan tidak semua pendapat dapat bersifat mengambang (floating) atau indikatif

7. Pengawasan terhadap pelaksanaan dilaksanakan oleh Dewan Pengawas Syariah dari aspek syariah, dan oleh wali amanat atau SPV dari segi operasional lapangan khususnya terhadap usaha emiten

8. Apabila emiten melakukan kelalaian atau melanggar syarat perjanjian, dilakukan pengembalian dana investor dan dibuat surat pengakuan utang,

9. Jasa asuransi syariah dapat digunakan untuk sebagai alat perlindungan risiko aset sukuk.

Ada beberapa akad penting lainnya yang dapat menjadi basis pengembangan obligasi syariah:

a. Musyarakah merupakan akad kerjasama antara dua pihak atau lebih untuk suatu usaha tertentu, dimana masing-masing pihak memberikan kontribusi dana dengan ketentuan bahwa keuntungan dan resiko akan ditanggung bersama sesuai kesepakatan

b. Murabahah adalah akad jual beli barang dimana pembeli dapat membayar harga barang yang disepakati pada jangka waktu tertentu yang telah disepakati. Penjual dapat menambah margin pada harga pokok barang yang dijual tersebut

c. Salam merupakan kontrak jual beli barang dengan cara pemesanan dan pembayaran harga lebih dahulu dengan syarat-syarat tertentu.

d. Karena akad tersebut banyak, namun sampai saat ini baru dua jenis obligasi syariah yang sedang berkembang di Indonesia, yaitu: obligasi mudharabah dan ijarah. Keduanya sesuai kaidah syariah namun berbeda dalam penghitungan, penilaian dan pemberian hasil (return).

\section{Struktur dan Kinerja Obligasi Syariah}

1. Struktur Obligasi Syariah 
Obligasi syariah sebagai bentuk pendanaan (financing) dan sekaligus investasi (investment) memungkinkan beberapa bentuk struktur yang dapat ditawarkan untuk tetap menghindarkan pada riba. Berdasarkan pengertian tersebut obligasi syariah dapat memberikan :

a. Bagi hasil berdasarkan akad mudharabah / muqaradhah / qiradh atau musyarakah adalah kerjasama dengan skema bagi hasil pendapatan atau keuntungan, obligasi jenis ini akan memberikan return dengan penggunaan term indicative (indikasi waktu) / expected return (tingkat pengembalian yang diharapkan) karena sifatnya yang floating(mengambang) dan tergantung pada kinerja pendapatan yang dibagihasilkan.

b. Margin/fee berdasarkan akad murabahah atau salam atau istishna atau ijarah, dengan kadar murabahah/salam/istishna sebagai bentuk jual beli dengan skema cost plus basis, (penambahan biaya) obligasi jenis ini akan memberikan fixed return (pengembalian tetap).

2. Kinerja Obligasi Syariah

Diawali dengan gebrakan Indosat pada akhir 2002 bahkan sebelum Pasar
Modal Syariah resmi berdiri, yang menerbitkan obligasi syariah mudharabah senilai Rp. 175 miliar, instrumen ini menarik perhatian pelaku pasar modal. Obligasi syariah mudharabah indosat memberikan nisbah bagi hasil indikatif sebesar 15,5 \% hingga $16 \%$ pertahun. Nisbah bagi hasil ini berarti sama dengan rate yang diberikan oleh obligasi Indosat konvensional.Bedanya nisbah obligasi syariah bersifat indikatif (bisa berubah tapi cenderung stabil), sedangkan nisbah obligasi konvensional bersifat tetap. Penawaran obligasi syariah Indosat ini mengalami kelebihan permintaan (oversubscribed) sampai $2 x$ lebih. Jumlah nilai obligasi syariah Indosat dinyatakan sebanyakbanyaknya Rp. 100 miliar, sampai akhir book building jumlah yang masuk Rp. 200 miliar. Kenyataan ini cukup menggembirakan karena sebelumnya banyak pihak yang skeptis menyambut kemunculan Islamic Bond pertama di Indonesia.

Karena berhasilnya penerbitan obligasi dari Indosat, maka pada 2003 mulailah sejumlah perusahaan menerbitkan instrumen sejenis, yakni PT. Ciliandra Perkasa, PT. Pembangunan Perumahan, PT. Berlian Laju Tanker, dan PT. Sinar 
Baru Lampung. Tentu saja tak ketinggalan sejumlah lembaga keuangan syariah seperti Bank Muamalah, Bank Syariah Mandiri, dan Bank Bukopin Syariah.

\section{Penerbit Obligasi Syariah (Sukuk)}

Penerbit obligasi ini sangat luas sekali, hampir setiap badan hukum dapat menerbitkan obligasi, namun peraturan yang mengatur mengenai tata cara penerbitan obligasi ini sangat ketat sekali. Penggolongan penerbit obligasi biasanya terdiri atas:

Lembaga supranasional, seperti misalnya Bank Investasi Eropa(European Investment Bank) atau Bank Pembangunan Asia (Asian Development Bank)

Pemerintah suatu negara, menerbitkan obligasi pemerintah dalam mata uang negaranya maupun obligasi pemerintah dalam denominasivaluta asing yang biasa disebut dengan obligasi internasional (sovereign bond) Subsovereign, propinsi,Negara atau otoritas daerah. Di Amerika dikenal sebagai obligasi daerah (municipal bond). Di Indonesia dikenal sebagai Surat Utang Negara (SUN) Lembaga pemerintah, obligasi ini biasa juga disebut agency bonds, atau agencies
Perusahaan yang menerbitkan obligasi swasta Special purpose vehicles adalah perusahaan yang didirikan dengansuatu tujuan khusus guna menguasai asset tertentu yang ditujukan gunapenerbitan suatu obligasi yang biasa disebut Efek Beragun Aset.

\section{METODE PENELITIAN}

\section{Jenis Penelitian}

Jenis penelitian yang digunakan dalam penelitian ini adalah penelitian deskriptif ,yaitu penelitian yang bertujuan untuk mengumpulkan data untuk diuji hipotesis atau menjawab pertanyaan mengenai status terakhir dari subjek penelitian yang berkaitan dengan penilaian sikap atau pendapat terhadap individu, organisasi, keadaan, ataupun prosedur (Kuncoro,2003;8).

\section{Jenis dan Sumber Data}

Jenis data dalam penelitian ini adalah :

a. Data kuantitatif yaitu data yang diperlukan dalam penelitian yang berupa angka angka yang dapat diukur besarnya dan dapat dihitung secara pasti.

b. Data kualitatif yaitu data yang diperlukan dalam penelitian ini berupa keterangan dan kebijakan tentang peluang dan tantangan 
penerbitan sukuk daerah sebagai sumber pembiayaan pembangunan daerah.

Sumber data dalam penelitian ini adalah:

a. Data primer adalah data yang diperoleh secara langsung dari responden yang dipilih oleh peneliti dengan pertimbangan tertentu yang dapat memberikan informasi atau keterangan yang diperlukan. Data primer diperoleh dari wawancara dengan stakeholder dalam penerbitan sukuk daerah nusa tenggara barat (NTB)

b. Data sekunder, adalah data yang diperoleh dari otoritas jasa keuangan (OJK) Kementerian keuangan ,Badan Pusat Statistik, Badan pengelolaan aset dan keuangan daerah (BPKAD) NTB

Teknik dan alat pengumpul data

Teknik yang digunakan dalam mengumpulkan data dalam penelitian ini sebagai berikut:

a. Dokumentasi yaitu pengumpulan data berupa catatan-catatan yang tersedia pada lembaga terkait

b. Studi kepustakaan, yaitu pengumpulan data dengan cara penelaahan kepustakaan dengan objek- objek yang akan dibahas dan bahan bacaan yang berhubungan dengan masalah yang diteliti.

c. Wawancara,yaitu teknik pengumpulan data dengan cara tanya jawab langsung dengan stakeholder sukuk daerah NTB

\section{Prosedur Analisis}

Teknik analisis yang digunakan adalah analisis SWOT (Strength, Weakness, Opportunity, Threat) untuk mengetahui strategi kebijakan Peluang dan tantangan penerbitan sukuk daerah NTB, analisis SWOT juga digunakan untuk mengkaji peluang, ancaman, kelebihan, dan kekurangan penerbitan sukuk daerah sebagai sumber dana pembangunan daerah serta menentukan strategi-strategi yang perlu ditempuh oleh pemerintah dalam rangka penerbitan obligasi daerah,

\section{Analisis SWOT}

Analisis SWOT yang digunakan dalam penelitian ini adalah untuk membandingkan antara faktor eksternal peluang (opportunities) dan ancaman (threats) dengan faktor internal kekuatan (strengths) dan kelemahan (weaknesses). 
Gambar 1 Diagram Analisis SWOT

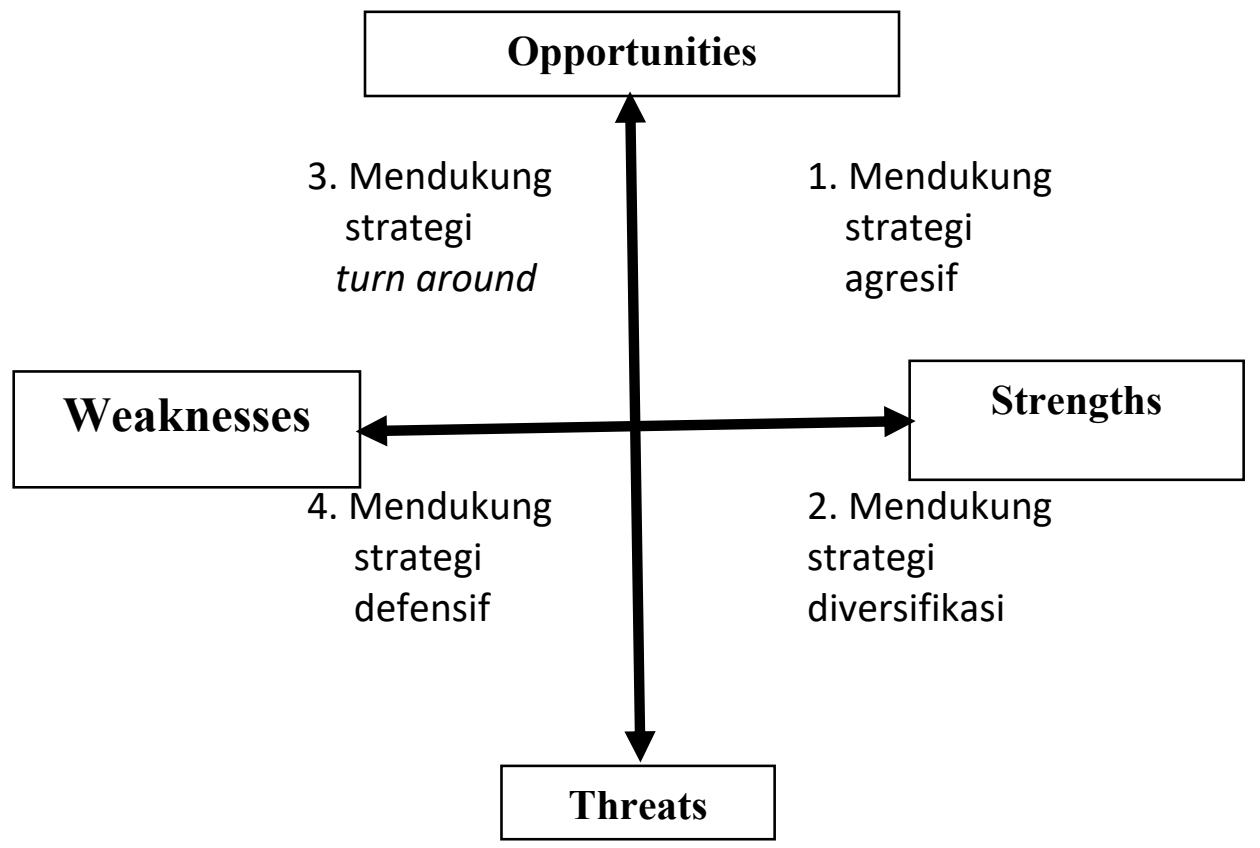

Sumber: Rangkuti (2002:19-20)

Penjelasan Gambar:

Kuadran 1: Merupakan situasi yang sangat menguntungkan, organisasi memiliki peluang dan kekuatan sehingga dapat memanfaatkan peluang yang ada. Strategi yang harus diterapkan dalam kondisi ini adalah mendukung kebijakan pertumbuhan yang agresif.

Kuadran 2: Meskipun menghadapi berbagai ancaman, organisasi masih memiliki kekuatan dari segi internal. Strategi yang harus digunakan adalah menggunakan kekuatan untuk memanfaatkan peluang jangka panjang.

Kuadran 3 : Organisasi menghadapi peluang yang sangat besar, tetapi dilain pihak, ia menghadapi beberapa kendala/kelemahan internal. Fokus strategi organisasi adalah meminimalkan masalah-masalah internal organisasi.

Kuadran 4: Ini merupakan situasi yang sangat tidak menguntungkan, organisasi menghadapi berbagai ancaman dan kelemahan.

Alat analisis yang dipakai untuk menyusun faktor-faktor strategis perusahaan adalah matriks SWOT, matrik ini dapat menggambarkan secara jelas bagaimana peluang dan ancaman eksternal yang dihadapi perusahaan yang dapat disesuaikan dengan kekuatan dan kelemahan yang dimiliki sehingga dapat menentukan alternatif strategi. 
Gambar 2 Matrik SWOT

\begin{tabular}{|c|c|c|}
\hline EFAS & $\begin{array}{c}\text { STRENGTHS (S) } \\
\text { Tentukan 5-30 kekuatan } \\
\text { internal }\end{array}$ & $\begin{array}{l}\text { WEAKNESSES }(\mathrm{W}) \\
\text { Tentukan 5-30 faktor } \\
\text { kelemahan internal }\end{array}$ \\
\hline $\begin{array}{c}\text { OPPORTUNITIES (O) } \\
\text { Tentukan 5-30 peluang } \\
\text { eksternal }\end{array}$ & $\begin{array}{l}\text { STRATEGI SO } \\
\text { Ciptakan strategi yang } \\
\text { menggunakankekuatan } \\
\text { untuk memanfaatkan } \\
\text { peluang }\end{array}$ & $\begin{array}{l}\text { STRATEGI WO } \\
\text { Ciptakan strategi yang } \\
\text { meminimalkankelemah } \\
\text { an untukmemanfaatkan } \\
\text { peluang }\end{array}$ \\
\hline $\begin{array}{c}\text { THREATS }(\mathrm{T}) \\
\text { Tentukan 5-30 ancaman } \\
\text { eksternal }\end{array}$ & $\begin{array}{l}\text { STRATEGI ST } \\
\text { Ciptakan strategi yang } \\
\text { menggunakankekuatan } \\
\text { untuk mengatasi } \\
\text { ancaman }\end{array}$ & $\begin{array}{l}\text { STRATEGI WT } \\
\text { Ciptakan strategi yang } \\
\text { meminimalkankelemah } \\
\text { an danmenghindari } \\
\text { ancaman }\end{array}$ \\
\hline
\end{tabular}

Sumber: (Rangkuti, 2002:31)

\section{HASIL DAN PEMBAHASAN}

1. Analisis SWOT Lingkungan Internal SUKUK Daerah

Table 1.Tabel Analisis SWOT faktor internal (kekuatan) SUKUK Daerah

\begin{tabular}{|l|l|l|l|l|}
\hline No & Faktor internal & Bobot & Rating & Skor \\
\hline & KEKUATAN & & & \\
\hline 1 & Keinginan membangun daerah tinggi & 0.08 & 3.50 & 0.28 \\
\hline 2 & Potensi investor muslim yg besar & 0.06 & 3.25 & 0.20 \\
\hline 3 & Jaringan perbankan yg luas & 0.06 & 2.50 & 0.15 \\
\hline 4 & Adanya obligasi ritel dgn harga terjangkau & 0.07 & 2.25 & 0.16 \\
\hline 5 & Imbal hasil yang menguntungkan & 0.08 & 3.30 & 0.26 \\
\hline & Total Bobot kekuatan & 0.35 & 14.8 & 1.05 \\
\hline
\end{tabular}

Sumber : data diolah

Dari tabel 1 analisis SWOT penelitian dengan melihat faktor internal SUKUK Daerah dengan menggunakan 5 Faktor seperti Faktor lokasi yang strategis, strategi jemput bola, pendidikan pengurus memadai, solidaritas yg tinggi antara pengurus dan pengelola serta memiliki kantor sendiri, dimana total keseluruhan nilai skor dari hasil pembobotan analisis SWOT adalah 1,05. Faktor strategi internal (kekuatan) yang memiliki nilai paling tinggi adalah lokasi yang strategis dengan skor tertinggi 0,28, artinya SUKUK Daerah di Nusa Tenggara Barat harus memiliki lokasi yang strategis yaitu lokasi yang 
dekat dengan nasabah, dekat dengan pusat ekonomi, dekat dengan pasar agar SUKUK Daerah di NTB dapat berkembang untuk dapat memberikan bantuan permodalan usaha kepada masyarakat miskin atau masyarakat menengah kebawah sehingga kemiskinan di NTB dapat berkurang. Faktor strategi internal (kekuatan) yang memiliki nilai paling tinggi kedua adalah SUKUK Daerah harus memiliki kantor sendiri dengan skor 0,26 artinya SUKUK Daerah di Nusa Tenggara Barat harus memiliki kantor sendiri agar dapat mempermudah pelayanan kepada masyarakat dan nasabah, selain itu juga SUKUK Daerah yang memiliki kantor sendiri akan lebih dipercaya Tabel 2 Tabel Analisis SWOT faktor internal (Kelemahan) SUKUK Daerah

\begin{tabular}{|l|l|l|l|l|}
\hline No & Faktor internal & Bobot & Rating & Skor \\
\hline & KELEMAHAN & & & \\
\hline 1 & Obligasi yg gagal bayar banyak & 0.04 & 2.50 & 0.10 \\
\hline 2 & Harga obligasi yg mahal & 0.06 & 1.25 & 0.08 \\
\hline 3 & Kurangnya sosialisasi sukuk & 0.05 & 2.50 & 0.13 \\
\hline 4 & Kurangnya promosi & 0.04 & 2.55 & 0.10 \\
\hline 5 & $\begin{array}{l}\text { Kurangnya pengetahuan } \\
\text { masyarakat }\end{array}$ & 0.03 & 1.20 & 0.04 \\
\hline & Total Bobot kelemahan & 0.22 & 10 & 0.44 \\
\hline
\end{tabular}

Sumber : data diolah

Dari tabel 2 analisis SWOT penelitian dengan melihat faktor internal SUKUK Daerah dengan menggunakan 5 Faktor seperti Faktor Kurangnya pemanfaatan TI, Tidak adanya ATM, Kurangnya sosialisasi, Kurangnya promosi, Belum oleh nasabah atau masyarakat karena dapat menunjukkan eksistensi Sukuk itu sendiri di mata nasabah atau masyarakat dan tentunya untuk lebih memudahkan operasional SUKUK Daerah dalam kegiatan pelayanan kepada nasabah atau masyarakat.

Untuk analisis SWOT faktor internal (Kekuatan) SUKUK Daerah di Nusa Tenggara Barat terlihat bahwa skor seluruh bobot kekuatan sebesar 1,05 artinya strategi internal yang diterapkan masih lemah karena nilai skor bobot kurang dari 2,5.

2 Analisis SWOT Lingkungan internal SUKUK Daerah 
dengan skor tertinggi 0,13 artinya SUKUK Daerah di Nusa Tenggara Barat harus melakukan sosialisasi dan promosi yang cukup gencar melalui pondok pesantren dan masjid-masjid agar masyarakat atau nasabah dapat menggunakan atau memanfaatkan produk SUKUK Daerah dengan baik sehingga tujuan SUKUK Daerah untuk memberikan kemaslahatan bagi masyarakat dapat tercapai.

Faktor strategi internal (Kelemahan) yang memiliki nilai paling tinggi kedua adalah kurangnya pemanfaatan IT (teknologi informasi) dengan skor 0,10 artinya SUKUK Daerah di Nusa Tenggara Barat belum menggunakan dan memanfaatkan teknologi dengan

baik agar pelayanan yang diberikan kepada nasabah atau masyarakat dapat maksimal sehingga SUKUK Daerah di Nusa tenggara barat masih tertinggal dengan lembaga keuangan lainnya seperti perbankan syariah atau lembaga keuangan lainnya yang sejenis.

Untuk analisis SWOT faktor internal (Kelemahan) Baitul SUKUK Daerah di Nusa Tenggara Barat terlihat bahwa skor seluruh bobot kelemahan sebesar 0,44 artinya strategi internal yang diterapkan masih lemah karena nilai skor bobot kurang dari 2,5.

3 Analisis SWOT Lingkungan eksternal SUKUK Daerah

Table 3 Tabel Analisis SWOT faktor Eksternal (Peluang) SUKUK Daerah

\begin{tabular}{|l|l|l|l|l|}
\hline No & Faktor eksternal & Bobot & Rating & Skor \\
\hline & PELUANG & & & \\
\hline 1 & Adanya berbagai aturan obligasi & 0.06 & 3.00 & 0.18 \\
\hline 2 & $\begin{array}{l}\text { Mempercepat pertumbuhan } \\
\text { ekonomi }\end{array}$ & 0.05 & 3.65 & 0.18 \\
\hline 3 & Potensi pasar sukuk yg luas & 0.04 & 2.80 & 0.11 \\
\hline 4 & Imbal hasil yg besar & 0.03 & 2.45 & 0.07 \\
\hline 5 & Memberdayakan Investor kecil & 0.07 & 3.15 & 0.22 \\
\hline & Total Bobot kekuatan & 0.25 & 15.05 & 0.77 \\
\hline
\end{tabular}

Sumber : data diolah

Dari tabel 3 analisis SWOT penelitian dengan melihat faktor eksternal SUKUK Daerah dengan menggunakan 5 Faktor seperti Faktor Potensi pasar SUKUK Daerah yg luas, Dekat dg pusat ekonomi, SUKUK Daerah memberdayakan UMKM, Sistem bagi hasil (syariah) SUKUK Daerah memberdayakan masyarakat miskin dimana total keseluruhan nilai skor dari hasil pembobotan analisis SWOT adalah 0,77. Faktor strategi Eksternal 
(Peluang) yang memiliki nilai paling tinggi adalah SUKUK Daerah memberdayakan masyarakat miskin dengan skor tertinggi 0,22 , artinya SUKUK Daerah di Nusa Tenggara Barat dapat berkembang dengan baik karena memiliki peluang untuk pemberdayaan masyarakat di Nusa tenggara barat melalui bantuan permodalan dan pembiayaan kepada sektor usaha mikro kecil sehingga akan dapat memberikan peluang juga untuk mengurangi kemiskinan di Nusa Tenggara Barat.

Faktor strategi Eksternal (Peluang) yang memiliki nilai paling tinggi kedua adalah Potensi pasar SUKUK Daerah yg luas dengan skor 0,18 artinya SUKUK Daerah di Nusa Tenggara Barat memiliki potensi pasar yang cukup

besar untuk dilayani dan diberikan bantuan permodalan melalui pembiayaan karena jumlah penduduk NTB yang mayoritas penduduknya muslim atau beragama islam sehingga tinggal diberikan pemahaman dan sosialisasi kepada masyarakat atau nasabah agar dapat memahami seluk beluk atau segala hal yang berkaitan dengan SUKUK Daerah

Untuk analisis SWOT faktor Eksternal (Peluang) SUKUK Daerah di Nusa Tenggara Barat terlihat bahwa skor seluruh bobot peluang sebesar 0,77 artinya strategi eksternal yang diterapkan masih lemah karena nilai skor bobot kurang dari 2,5.

4 Analisis SWOT Lingkungan eksternal SUKUK Daerah

Tabel 4 Tabel Analisis SWOT faktor Eksternal (Ancaman) SUKUK Daerah

\begin{tabular}{|l|l|l|l|l|}
\hline No & Faktor eksternal & Bobot & Rating & Skor \\
\hline & ANCAMAN & & & \\
\hline 1 & $\begin{array}{l}\text { Meningkatkan utang pemerintah } \\
\text { daerah }\end{array}$ & 0.03 & 2.70 & 0.08 \\
\hline 2 & Meningkatkan risiko utang pemerintah & 0.05 & 1.70 & 0.09 \\
\hline 3 & Kualitas SDI masih kurang & 0.04 & 2.30 & 0.09 \\
\hline 4 & Kurangnya penggunaan TI & 0.03 & 2.35 & 0.07 \\
\hline 5 & Adanya berbagai obligasi Negara lain & 0.06 & 3.48 & 0.21 \\
\hline & Total Bobot kelemahan & 0.21 & 12.53 & 0.54 \\
\hline
\end{tabular}

Sumber : data diolah

Dari tabel 4 analisis SWOT penelitian dengan melihat faktor eksternal SUKUK Daerah dengan menggunakan 5 Faktor seperti Faktor Kurangnya modal SUKUK Daerah, Kualitas SDI masih kurang,
Adanya KUR, Kurangnya penggunaan TI, Bank syariah yg menggarap pasar mikro dimana total keseluruhan nilai skor dari hasil pembobotan analisis SWOT adalah 0,54. Faktor strategi 
Eksternal (Ancaman) yang memiliki nilai paling tinggi adalah Bank syariah yg menggarap pasar mikro dengan skor tertinggi 0,21 artinya SUKUK Daerah di Nusa Tenggara Barat memiliki pesaing yang cukup berat yaitu dari bank syariah yang mulai menggarap sektor mikro atau nasabah mikro kecil yang selama ini menjadi pasar yang cukup potensial bagi SUKUK Daerah di Nusa Tenggara Barat, belum lagi adanya pesaing dari bank konvensional yang selama ini menggarap sektor mikro kecil seperti bank BRI konvensional yang telah lebih dahulu menggarap sektor mikro dan cukup berpengalaman dalam bidang ini sehingga factor ini menjadi ancaman yang cukup serius bagi SUKUK Daerah di Nusa Tenggara Barat.

Faktor strategi Eksternal (ancaman) yang memiliki nilai paling tinggi kedua adalah adanya KUR (Kredit usaha rakyat) artinya SUKUK Daerah di Nusa Tenggara Barat memiliki ancaman dari pesaing perbankan konvensional yang memberikan fasilitas KUR kepada nasabah mikro kecil sehingga pangsa pasar SUKUK Daerah di Nusa tenggara barat semakin berkurang dan persaingan untuk mendapatkan nasabah atau anggota SUKUK Daerah semakin ketat.

Untuk analisis SWOT faktor Eksternal (ancaman) SUKUK Daerah di Nusa Tenggara Barat terlihat bahwa skor seluruh bobot ancaman sebesar 0,54 artinya strategi eksternal yang diterapkan masih lemah karena nilai skor bobot kurang dari 2,5.

\section{Pembahasan}

1. Dari analisis SWOT diatas terlihat bahwa Faktor strategi internal (Kekuatan) yang memiliki nilai paling tinggi adalah Kurangnya sosialisasi dengan skor tertinggi 0,13 artinya SUKUK Daerah di Nusa Tenggara Barat harus melakukan sosialisasi dan promosi yang cukup gencar melalui pondok pesantren dan masjid-masjid agar masyarakat atau nasabah dapat menggunakan atau memanfaatkan produk SUKUK Daerah dengan baik sehingga tujuan BMT untuk memberikan kemaslahatan bagi masyarakat dapat tercapai. Faktor strategi internal (Kelemahan) yang memiliki nilai paling tinggi adalah Kurangnya sosialisasi dengan skor tertinggi 0,13 artinya SUKUK Daerah di Nusa Tenggara Barat harus melakukan sosialisasi dan promosi yang cukup 
gencar melalui pondok pesantren dan masjid-masjid agar masyarakat atau nasabah dapat menggunakan atau memanfaatkan produk sukuk daerah dengan baik sehingga tujuan sukuk daerah untuk memberikan kemaslahatan bagi masyarakat dapat tercapai. Faktor strategi Eksternal (Peluang) yang memiliki nilai paling tinggi adalah sukuk daerah memberdayakan masyarakat miskin dengan skor tertinggi 0,22 , artinya SUKUK Daerah di Nusa Tenggara Barat dapat berkembang dengan baik karena memiliki peluang untuk pemberdayaan masyarakat di Nusa tenggara barat melalui bantuan permodalan dan pembiayaan kepada sektor usaha mikro kecil sehingga akan dapat memberikan peluang juga untuk mengurangi kemiskinan di Nusa Tenggara Barat. Faktor strategi Eksternal (Ancaman) yang memiliki nilai paling tinggi adalah Bank syariah yg menggarap pasar mikro dengan skor tertinggi 0,21 artinya SUKUK Daerah) di Nusa Tenggara Barat memiliki pesaing yang cukup berat yaitu dari bank syariah yang mulai menggarap sektor mikro atau nasabah mikro kecil yang selama ini menjadi pasar yang cukup potensial bagi sukuk daerah di Nusa Tenggara Barat, belum lagi adanya pesaing dari bank konvensional yang selama ini menggarap sektor mikro kecil seperti bank BRI konvensional yang telah lebih dahulu menggarap sektor mikro dan cukup berpengalaman dalam bidang ini sehingga factor ini menjadi ancaman yang cukup serius bagi BMT di Nusa Tenggara Barat. Dari hasil analisis SWOT diatas juga dapat dirumuskan strategi pengembangan SUKUK Daerah di Nusa Tenggara Barat (NTB) sebagai berikut ;

2. Melakukan sosialisasi tentang konsep keuangan mikro syariah SUKUK Daerah ke masyarakat.

3. Pelatihan kepada pegawai SUKUK Daerah berkaitan dgn pemasaran dan pelayanan nasabah

4. Menambah teknologi pendukung untuk operasional SUKUK Daerah

5. Membuat website dan mempromosikan produk SUKUK Daerah

6. Membangun relationship dengan masyarakat sekitar 
7. Turun ke pasar-pasar / jemput bola untuk mencari nasabah/anggota SUKUK Daerah

KESIMPULAN DAN SARAN

\section{Kesimpulan}

1. Dengan adanya penerbitan sukuk daerah ini akan memberikan peluang kepada pemerintah daerah untuk mendapatkan sumber pembiayaan yang cukup besar untuk mempercepat pembangunan daerah dengan berbagai peraturan perundangan undangan yang mendukung.

2. Hambatan yang sering dihadapi dalam penerbitan obligasi daerah (sukuk) ini adalah pemahaman masyarakat tentang obligasi yang masih kurang terutama tentang sukuk daerah sehingga perlu dilakukan sosialisasi kepada masyarakat dengan berbagai media dan pemanfaatan teknologi informasi

3. Strategi pengembangan sukuk daerah adalah dengan mempersiapkan infrastruktur untuk penjualan dan pembelian sukuk daerah terutama bekerjasama dengan pihak bank Terutama bank syariah serta melakukan sosialisasi dan pelatihan yang berkaitan dengan penerbitan sukuk daerah terutama bagi staf pengelola keuangan daerah.

\section{Saran}

1. Pemerintah daerah NTB harus melakukan sosialisasi dengan gencar agar sukuk daerah dapat terserap oleh investor baik investor lokal maupun investor asing.

2. Pemerintah daerah harus menghitung dengan cermat sebelum menerbitkan sukuk daerah dengan melakukan kajian rasio hutang terhadap PDRB NTB agar nantinya tidak terjadi gagal bayar hutang dan meningkatkan risiko utang pemerintah terutama pemerintah daerah.

3. Pihak perbankan yang ditunjuk sebagai dealer penjualan sukuk daerah tersebut harus memanfaatkan seluruh jaringan perbankan sampai ke daerahdaerah agar sukuk daerah tersebut terjual dan terserap oleh investor 


\section{DAFTAR PUSTAKA}

Antonio,Syafi' i.2001.Bank Syariah "Dari teori ke praktek". Gema Insani Press.Jakarta

Gozali, Ahmad, 2004, Halal, Berkah dan Bertambah, "Mengenal dan Memilih Produk Investasi Syariah", Edisi Pertama. Jakarta , Elex Media Komputindo

Harun, Nasroen, 2002, Perdagangan Saham di Bursa Efek, "Tinjauan Hukum Islam", Edisi Pertama, Jakarta, Yayasan Kalimah

Jogiyanto, 1998, Teori Portfolio dan Analisis Investasi. Edisi Pertama, Jogjakarta BPFE.

Jones, Charles P, 2001, Investment "Analysis and Management ", Third edition, John Willy Inc.

Karim, Adiwarman , 2005, Bank Is/am,"Analisis Fiqih dan Keuangan" Jakarta , Rajawali Press.

Kuncoro, Mudrajad, 2003, Metode Riset untuk Bisnis dan Ekonomi : Bagaimana Meneliti dan Menulis tesis? , Erlangga , Jakarta.

Muhammad, 2003, Dasar-dasar Keuangan Islam, Yogyakarta , Ekonisia.

Muhammad, 2002, Metodologi Penelitian Ekonomi Islam, Yogyakarta, Ekonisia

Nurul Huda dan Mustafa Edwin Nasution,2010, Investasi pada Pasar Modal Syari'ah, Kencana Prenada Media Group. Jakarta

Nurul Huda dan Mohamad Heykal, 2010.Lembaga Keuangan Islam:Tinjauan Teoritis dan Praktis .Kencana Prenada Media Group. Jakarta

Raharjo, Sapto, 2003, Panduan Investasi Obligasi, Jakarta, Gramedia Pustaka Utama.

Rangkuti, Freddy. 2002. Analisis SWOT Teknik Membedah Kasus Bisnis, PT. Gramedia Pustaka Utama: Jakarta.

Sudarsono,Heri.2008.Bank dan Lembaga Keuangan Syariah"Deskripsi dan Ilustrasi". Edisi 3. Ekonisia.Yogyakarta.

Sahatah, Husen dan Atiyah., 2004, Bursa Efek. "Tuntutan Menurut Islam dalam Transaksi di pasar Modal", Edisi pertama, Surabaya , Pustaka Progresif.

Tjiptono \& Fahrudin, 2001, Pasar Modal di Indonesia Pendekatan Tanya Jawab. Jakarta, Salemba Empat.

Antonio,Syafi'i.2001.Bank Syariah "Dari teori ke praktek". Gema Insani Press.Jakarta 